\title{
DÜBLIN
}

Technological University Dublin ARROW@TU Dublin

2010-05-01

\section{Design of a Single Alkaline Fuel Cell Test Bed}

\author{
James Brunton \\ Technological University Dublin, James.Brunton@tudublin.ie \\ David Kennedy \\ Technological University Dublin, david.kennedy@tudublin.ie \\ Fergal O'Rourke \\ Technological University Dublin, fergal.orourke@tudublin.ie
}

See next page for additional authors

Follow this and additional works at: https://arrow.tudublin.ie/engschmeccon

Part of the Mechanical Engineering Commons

\section{Recommended Citation}

Brunton, J.; Kennedy, D.; O'Rourke, F.; Coyle, E.; Design of a single alkaline fuel cell test bed. EEEIC: 9th. International Conference on Environment and Electrical Engineering, Prague, Czech Republic, 16-19 May, 2010. doi: 10.1109/EEEIC.2010.5490009

This Conference Paper is brought to you for free and open access by the School of Mechanical and Design Engineering at ARROW@TU Dublin. It has been accepted for inclusion in Conference Papers by an authorized administrator of ARROW@TU Dublin. For more information, please contact arrow.admin@tudublin.ie, aisling.coyne@tudublin.ie,gerard.connolly@tudublin.ie.

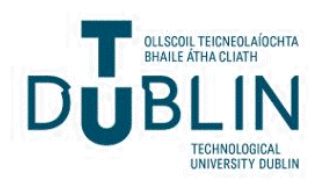




\section{Authors}

James Brunton, David Kennedy, Fergal O'Rourke, and Eugene Coyle

This conference paper is available at ARROW@TU Dublin: https://arrow.tudublin.ie/engschmeccon/18 


\title{
Design of a Single Alkaline Fuel Cell Test Bed
}

\author{
J.Brunton, D.M. Kennedy, F.O'Rourke and E. Coyle \\ School of Mechanical and Transport Engineering \\ Dublin Institute of Technology \\ Bolton Street, Dublin 1 \\ James.brunton@dit.ie
}

\begin{abstract}
This Research focuses on the design and development of a single alkaline fuel cell test bed facility. The paper also makes reference to problems and solutions encountered during construction that resulted in a more effective fuel cell and operating system. As a sustainable and clean alternative energy option, fuel cell technology has the potential to provide electrical power for stationary and mobile applications. Hydrogen and fuel cell technologies are a viable long term energy solution, but todate has failed to make a major impact on the energy market. Fuel Cells offer a sustainable energy options that can be cost effective and mass-produced.
\end{abstract}

Keywords- Alkaline fuel cell, single cell test bed, hydrogen fuel cell technology, EloFlux technology

\section{INTRODUCTION}

A fuel cell is an electrochemical device that continually converts chemical energy into electrical energy (and heat) for as long as a fuel and oxidant are supplied[1]. The fuel cell achieves this conversion via electrochemical reactions that occur at the electrodes when they are connected as part of an external circuit. Conventional batteries have a tendency to consume materials that form an integral part of, or are stored within its structure where as a fuel cell does not. The fuel cell will continue to operate as long as it is supplied with a suitable fuel (hydrogen) and oxidant (oxygen) and the reaction products (water and heat) are removed.

Pure oxygen $\left(\mathrm{O}_{2}\right)$ or air is used as the oxidant and the most commonly used fuel is pure hydrogen $\left(\mathrm{H}_{2}\right)$. Other hydrogen rich fuels such as gasoline, methanol, ethanol, methane and natural gas can be reformed, producing hydrogen gas to be utilised in the fuel cell. If the cell uses pure hydrogen the process results in zero emissions, but the reforming of these fuels emit harmful pollutants into the atmosphere[2].

As part of the fuel cell process, the reactants are fed from outside the cell to the electrodes when electric power generation is required. The electrodes are coated with a catalyst, such as platinum to increase the rate of reaction. The hydrogen is oxidised at the anode by transferring electrons to the anode and the oxygen is reduced at the cathode by accepting electrons from the cathode. The current generated by the flow of electrons from the anode to the cathode (Galvanic cell) can be used to service external loads, e.g. motors, lights, etc., and the dc voltage can be inverted to suit ac applications. When the reactants are exhausted the external cylinders can be recharged to resume operations[3].

The nominal voltage of a single fuel cell is approximately $1.05 \sim 1.23$ volts unloaded dropping to $0.7 \sim 0.9$ volts when a load is applied. This depends on the cell type and design. Therefore in order for fuel cells to be used in a practical application, a number of individual cells are joined together to form a fuel cell stack. A single fuel cell has a high current and low voltage output, so cells are joined together in series or parallel to suit required application. Based on the nominal voltage when loaded the number of cells in the stack determines the total voltage and the cell surface area determines the current.

\section{A. Electrolysis and the Electrolytic Cell.}

Electrolysis of water is a process where current is passed through an electrolyte causing water to break up into its hydrogen and oxygen constituent elements. It is essentially the fuel cell in reverse and a very useful method of producing pure hydrogen for local or commercial use. Hydrogen gas is produced at the cathode (negative electrode) and the chemical equation for the reduction of water at this electrode is:

$$
\mathrm{H}_{2} \mathrm{O}+2 \mathrm{e}^{-} \rightarrow \mathrm{H}_{2}+\mathrm{O}_{2}
$$

Oxygen gas is produced at the anode (positive electrode) and the donation of electrons due to oxidation at the electrode is expressed as:

$$
\mathrm{H}_{2} \mathrm{O} \rightarrow 1 / 2 \mathrm{O}_{2}+2 \mathrm{H}^{+}+2 \mathrm{e}^{-}
$$

To avoid cross contamination during electrolysis, the cell is usually divided. This allows the gas bubbles formed at the electrodes to rise and gather in their respective container[4].

\section{B. $\quad$ Alkaline Fuel Cells (AFC)}

Alkaline Fuel Cells (AFC's) are a highly efficient, low temperature $\left(50 \sim 100^{\circ} \mathrm{C}\right)$ and relatively low in cost. AFC's use of a corrosive electrolyte called potassium hydroxide $(\mathrm{KOH})$, which have an inability to use air as an oxidant, (presence of $0.03 \% \mathrm{CO}_{2}$ )[5]. However these problems can be rectified. Some advantages of using an AFC include:

- Use of inexpensive catalysts and membranes

- High voltage at comparable current densities

- No damage by carbon monoxide (CO) contamination

- The purity of the hydrogen used is not a critical factor to efficient operation

\section{The EloFlux Alkaline Fuel Cell}

This system was considered unique in that unlike conventional alkaline fuel cells that utilised a vertical electrolyte flow, the EloFlux electrolyte was pressed 
perpendicular to the electrodes through the whole stack and the gas flow[5]. Therefore, the electrodes and the diaphragms contained an interconnecting system of narrow pores in which the electrolyte was dispersed. This area is referred to as the triple boundary point, and for the reaction to take place three elements must be present; a fuel, a catalyst and an electrolyte. For the cell to operate; the bigger pores must fill with pressurized hydrogen or oxygen (dependant on electrode), which flows independently of the electrolyte. Due to the different pore sizes the gases cannot enter the narrow pores and this is critical as any gas crossover or leakage causes a malfunction of the cell.

\section{Characteristics of the Alkaline Fuel Cell.}

- Cell Dimensions, 110 × 220 × 25mm,

- Open circuit potential $\sim 1.05 \mathrm{~V}$, Loaded $0.7 \mathrm{~V} \sim 20 \mathrm{~A}$, delivering $14 \mathrm{~W}$,

- Previous AFC's: $150 \mathrm{~mA} / \mathrm{cm}^{2}\left(50^{\circ} \mathrm{C}, 0.7 \mathrm{~V}\right), 85 \mathrm{~mA} / \mathrm{cm}^{2}$ $\left(23^{\circ} \mathrm{C}, 0.7 \mathrm{~V}\right)$.

- Test bed cell; $250 \mathrm{~mA}$ at high temperature, $150 \mathrm{~mA}$ at low temperature.

- Active surface area; $\sim 100 \mathrm{~cm}^{2}$, electrode size $170 \mathrm{~mm} \times$ $100 \mathrm{~mm}$

- With an active surface area of $100 \mathrm{~cm}^{2}$, and delivering 20 A, $0.7 \mathrm{~V}$ at $50^{\circ} \mathrm{C}$, this correspondents to $0.2 \mathrm{~A} / \mathrm{cm}^{2}$.

- Pressure: hydrogen 0.5 bar, Oxygen 0.5 bar.

- $\quad$ This cell uses $\mathrm{KOH} 7 \mathrm{M}$ at $50^{\circ} \mathrm{C}$, or alternatively Sodium Hydroxide $(\mathrm{NaOH})$ at $70^{\circ} \mathrm{C}$.

\section{Fuel CELl CONSTRUCTION}

The EloFlux fuel cell was manufactured as a single compact unit two hydrogen electrodes and two oxygen electrodes. The gas and electrolyte supply for the cell were initially located at the top of the cell. This was creating problems inside the cell and for the operating system. Following testing and analysis, it was decided to transfer the gas and electrolyte supply to the base of the cell. Therefore the hydrogen and oxygen will rise unimpeded through the cell. This prevents the formation of trapped bubbles that were affecting the cells initial operation.

The cell as part of its construction has two electrolyte distributors ( $\mathrm{KOH} 1$ and $\mathrm{KOH} 2)$, and it is possible to connect them in series or parallel. Two heating elements were fitted between the positive and negative poles to enhance cell heating. The wiring for the two heating foils can be connected in either series (24 VDC, 1A) or parallel (12 VDC, 2A).

Initial heating of the cell using the internal heating foils raised cell temperature but as soon as the electrolyte commenced circulation, the temperature of the cell dropped and could not be kept constant. For experimentation purposes a return beaker positioned on a hot plate was used as a reservoir for heating the electrolyte. The cell operates efficiently at between $50^{\circ} \mathrm{C} \sim 55^{\circ} \mathrm{C}$ and must be used in conjunction with some form of temperature control. To monitor the cell temperature and prevent overheating a $\mathrm{Pt} 100$ resistor was positioned inside the cell in close proximity to each element.
To prevent gas or electrolyte crossover at the electrode pores, the cell was operated at a gas pressure of approximately 50,000 Pascal. If crossover occurred, the cell became inactive and malfunctioned, causing the electrical power supply to the external system to collapse.

\section{A. Inner Construction}

The inner construction of the EloFlux fuel cell is shown in Figure 1. From left to right is the first passive separator followed by a pair of hydrogen $\left(\mathrm{H}_{2}\right)$ electrodes, the active separator, a pair of oxygen $\left(\mathrm{O}_{2}\right)$ electrodes and the second passive separator. The electrolyte is mobile and the flow is horizontal from left to right through all the components. The gas flows are vertical and only through their respective electrodes.

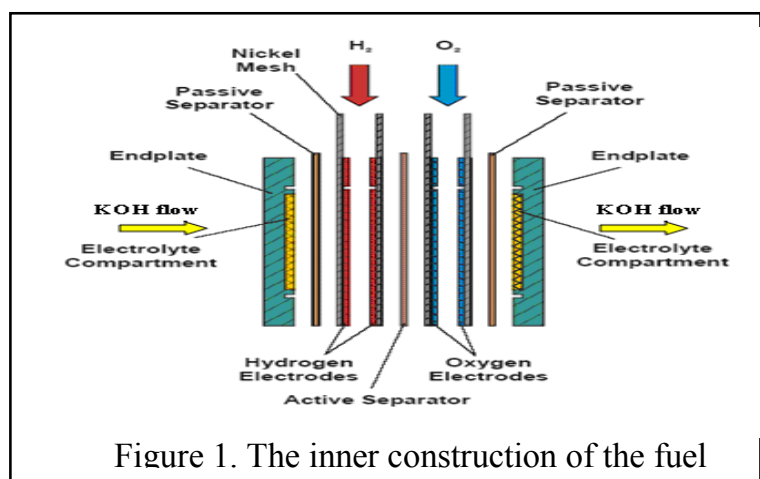

1) The Separators

The Active Separator is made from a porous plastic film, if the electrolyte wets it, then the $\mathrm{KOH}$ electrolyte can pass through it but the gas cannot, up to a pressure of 1 bar approximately (this limit is called the bubble point). If this pressure (bubble point) is exceeded then the gas will push the electrolyte out of the pores. The passive separators are not involved in the actual reaction process and only separate the $\mathrm{KOH}$ and gas chambers from each other. The function of the active separator is to separate the hydrogen gas stream from the oxygen gas stream (anode from cathode), insulating the electrodes from each other to prevent a short circuit. As part of the normal cell reaction when the ions are migrating from one electrode to the other, they must pass through the active separator. This is the main distinction between the two separators.

\section{2) The Electrodes}

For improved performance, the cell uses gas-diffused electrodes (GDE) as part of its construction. The hydrogen electrode at the anode side is made of Raney nickel and polytetrafluoroethylene (PTFE), a stable wet proofing agent to bind them together, and the oxygen electrode at the cathode is made of silver and PTFE. Nickel has a high catalytic activity for hydrogen oxidation and Raney metals are a good solution to achieving the activity and porosity needed in an electrode[5].

Raney metals are formed through mixing an active metal with an inactive metal like aluminium. The inactive material (aluminium) is then removed from the mixture by dissolving it in a strong alkali. What remains is an active porous nickel material with a large surface area. 
The pore sizes and distribution depend on the ratio of nickel to aluminium (usually 1: 1) and the particle size[6]. The EloFlux electrode consists of a nickel net with a film of carbon. The nickel net provides good electrical conductivity and mechanical stability. The carbon net has narrow hydrophilic pores where the $\mathrm{KOH}$ can pass and larger hydrophobic pores where gas can pass. The gas enters the electrode at the gas port and moves along the gas header from where it is distributed over the electrode.

\section{3) Electrolyte}

In $\mathrm{AFC}$ systems, the preferred electrolyte is aqueous $\mathrm{KOH}$, which has a higher conductivity than $\mathrm{NaOH}[5]$. The conductivity of concentrated $\mathrm{KOH}$ rises with temperature. Automotive vehicles must perform effectively and reliably in different environments so it is important that any fluids utilised in a transport situation have a high boiling and low freezing point. Another desirable feature is its ability to maintain a stable viscosity regardless of the temperatures or conditions it operates under. The percentage concentration of $\mathrm{KOH}$ to $\mathrm{H}_{2} \mathrm{O}$ has an effect on the boiling point of the electrolyte used in an $\mathrm{AFC}$, as the concentration increases, the boiling point increases. The specifications supplied with the cell recommended an electrolyte concentration of $7 \mathrm{M}$. This corresponds to mixes of between $30 \% \sim 40 \% \mathrm{KOH}$ and $\mathrm{H}_{2} \mathrm{O}$ and offers a boiling point value between $111^{\circ} \mathrm{C} \sim 127^{\circ} \mathrm{C}(232$ $\left.{ }^{\circ} \mathrm{F} \sim 260{ }^{\circ} \mathrm{F}\right)$. However as the electrolyte concentration increases, the freezing point decreases, offering only a set performance range between $24 \% \sim 44.3 \%$ for designing a reliable cell/system[7]. Many countries experience subzero conditions in winter and this could lead to cell destruction due to freezing. The expansion due to freezing could also lead to system damage at various points of the vehicle, (internal cell damage, fractured pipes and valves, etc) exposing the vehicle structure to a corrosive liquid. Vehicle damage coupled with the risk of occupant exposure to a caustic electrolyte or fumes is a reason why motor manufacturers have steered clear of AFC technology.

The $\mathrm{KOH}$ concentration of the electrolyte used as part of this research was determined as follows. From the periodic table it was possible to determine the collective molecular weight of $\mathrm{KOH}$ by adding the individual atomic weights. 1 mole solution is the molecular weight dissolved in 1 litre of distilled $\mathrm{H}_{2} \mathrm{O}$. The fuel cell electrolyte has a concentration of 7 mole (M) and was mixed. For practical purposes if required it may be possible to improve the freezing point of the $\mathrm{KOH}$ still further by using additives but they would need to be Potassium ion $\left(\mathrm{K}^{+}\right)$or Hydroxyl ion $\left(\mathrm{OH}^{-}\right)$friendly or electrically neutral so as not to impair the conductivity of the electrolyte.

\section{COMPONENTS}

\section{A. Gas Supply to Rig}

The storage gas supply for the test bed was provided by two 50 litre industrial bottles of compressed $\mathrm{H}_{2}$ and $\mathrm{O}_{2}$ pressurized to 200 bar.The price of $\mathrm{H}_{2}$ gas varies greatly with the purity required, but the cell operated efficiently on normal $\mathrm{H}_{2}$ gas.

\section{B. Multistage Regulator}

A good quality regulator should be robust enough to withstand the full gas pressure within the cylinder and maintain effective control of the outlet gas, while also displaying the cylinder content. As an added safety precaution two multistage regulators suitable for hydrogen and oxygen supply were sourced and fitted to each bottle. Multistage regulation reduces the cylinder pressure in two stages and the main benefit of this is that regardless of cylinder volume the gas pressure for the cell will not be affected, so the cell can be left operating under load without the gas pressures falling off or requiring further adjustment once set.

\section{Pressure Reducer}

For the cell to operate properly, accurate pressure reduction is required. This function was performed by a specialised pressure reducer that safely reduced the $\mathrm{O}_{2}$ and $\mathrm{H}_{2}$ gases from $10 \mathrm{bar}$ to the required cell operating pressure of 0.5 bar. The reducer used in this instance was a Minilabo $2 \mathrm{VH}$ with needle metering valve, suitable for use with $\mathrm{H}_{2}$ and $\mathrm{O}_{2}$ gas.

\section{Purge Valve}

The $\mathrm{H}_{2}$ and $\mathrm{O}_{2}$ gases enter the base of the fuel cell and move vertically upwards through the sealed unit, exiting diagonally at the top of the cell. At the gas outlet side, the flow rate of the $\mathrm{H}_{2}$ and $\mathrm{O}_{2}$ gases through the cell were each controlled by a separate adjustable purge valve. Before start-up, the valve allows the fuel cell to be purged of any trapped inactive gas and moisture that may impede the cells operation and performance. Following start-up the purge valves were adjusted until a specific bubble count for each gas was achieved.

\section{E. Circulating Electrolyte System}

The $\mathrm{KOH}$ electrolyte is the charge carrier of the cell, $\mathrm{OH}^{-}$ ion migrates continuously from the cathode to the anode and $\mathrm{H}_{2} \mathrm{O}$ migrates in the opposite direction.

In an AFC most of the reaction $\mathrm{H}_{2} \mathrm{O}$ exists on the anode $\left(\mathrm{H}_{2}\right)$ side, but a small amount of reaction $\mathrm{H}_{2} \mathrm{O}$ is removed via the circulating electrolyte loop. The formation of $\mathrm{H}_{2} \mathrm{O}$ at the anode effects the electrolyte concentration in the cell and in non-circulating systems the result is a drop in cell output voltage. A circulating electrolyte system helps to replenish the $\mathrm{KOH}$ electrolyte inside the cell and extend its operating life[8].

An electrolyte reservoir was provided as part of the test bed construction, 1.5 litres of electrolyte was stored in the reservoir and under normal conditions was circulated by a pump through an on/off valve into the bottom of the cell where it travels unimpeded horizontally through the cell, returning to the reservoir via another on/off valve.

With a circulating electrolyte, a small amount of $\mathrm{CO}_{2}$, can be tolerated as a circulated liquid electrolyte has a very small capacity to absorb $\mathrm{CO}_{2}$. This prevents the formation of potassium carbonate $\left(\mathrm{K}_{2} \mathrm{CO}_{3}\right)$, a crystalline deposit that can block electrode pores rendering the cell inactive. This is important for vehicular applications as it means that a circulating system coupled with a simple absorbing tower (with 
soda lime or amines) can use air (which contains $0.03 \% \mathrm{CO}_{2}$ ) as an oxidant[5].

\section{1) Electrolyte Storage}

To allow for various temperature conditions while conducting experimental tests the $\mathrm{KOH}$ was stored in a large Pyrex beaker. This was practical for rapid heating-up of the cell in conjunction with the internal heating foils. It was found that the cell temperature could not be maintained at the present figure once the electrolyte began to circulate. To solve this, the Pyrex beaker was placed on a hot plate and the electrolyte supply was heated, though not excessively to compensate for heat loss due to circulation. The cell temperature was monitored by a linearised temperature circuit and manually controlled by adjusting the 24 colt 1 amp power supply to the heating foils.

\section{2) The Circulation Pump}

In the EloFlux AFC System the circulating electrolyte regulates the cell temperature, removes reaction $\mathrm{H}_{2} \mathrm{O}$ from the cell, replenishes the cell with fresh $\mathrm{KOH}$ and cleans the cell of any carbonate deposits. The pump used to circulate the electrolyte on the single cell test bed was the Iwaki Electromagnetic Metering pump. The benefit of using this pump was that it did not draw the electrolyte into the pump and so the moving parts were not attacked by the caustic $\mathrm{KOH}$.

\section{OPERATIONAL AFC SYSTEM}

When operated the Eloflux AFC single cell system achieved its full unloaded voltage reading $\left(1.05 \mathrm{~V} @ 50^{\circ} \mathrm{C}\right)$ proving that the cell as part of fuel cell stack has the potential to satisfy commercial requirements. The complete system is shown in Figure 2.

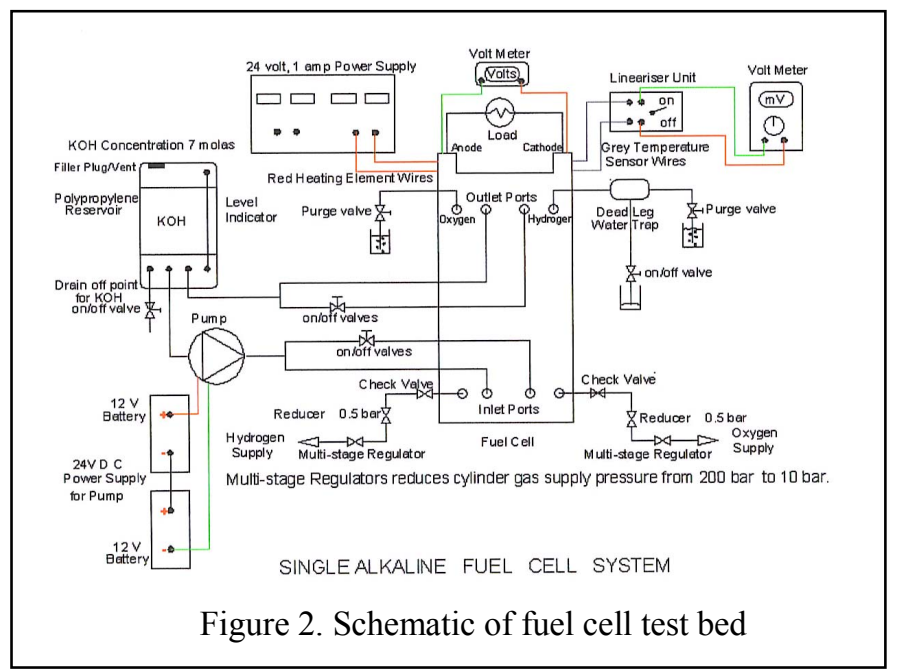

\section{OTHER USES}

For automotive operations a low temperature cell that is highly efficient and cost effective is desirable. Another drawback of using $\mathrm{KOH}$ as opposed to another alkaline electrolyte such as $\mathrm{NaOH}$ is that its viscosity varies dramatically with changes in temperature between $40 \sim 100^{\circ} \mathrm{C}$, and this combined with its small molecular structure makes it hard to confine and store, resulting in weeping joints and leaking from cracks and minor pin holes. The viscosity is improved by increasing the concentration.

As part of the cells normal reaction process, water forms and is absorbed by the $\mathrm{KOH}$, thus decreasing its concentration, but one of the main concerns regarding the use of $\mathrm{KOH}$ is that it absorbs carbon dioxide from air, requiring the use of pure oxygen as an oxidant and its caustic and destructive nature. It is incompatible with most metals and reacts vigorously with a wide variety of materials such as aluminum, zinc, brass, bronze and copper, making them completely unsuitable as component materials for any part of a systems construction. These factors were taken into account when designing the circulating system. $\mathrm{KOH}$ contact with components, (pumps, valves and gauges) made from materials other than stainless steel, polypropylene or nickel resulted in their destruction. $\mathrm{KOH}$ is also extremely toxic for humans and should be handled with care.

\section{CONCLUSIONS}

The fuel cell system is dynamic and the cell is affected by small changes in gas supply, pressure variations and temperature, requiring constant monitoring and control. In a fuel cell stack the circulating electrolyte cools, cleans and replenishes the cell but further experimentation using this test bed will indicate if a stationary electrolyte fuel cell similar to that used as part of the Apollo space program is a more efficient application.

Advancements in engineering and materials used in the construction of fuel cells have increased their power density to such a level that a stack the size of a small suitcase can be used to power a standard car. Because fuel cells and their operating systems are still at the prototype stage, the cost of constructing a single cell test bed as described in this article is expensive.

1. Hoogers, G., Fuel Cell Technology Handbook. 2003: CRC Press.

2. U.K. Department of Transport, Powering Future Vehicles, Draft Government Stragegy. 2004.

3. Cook, B., An Introduction to Fuel Cell Technology. 2001, Canada: Heliocentre.

4. Electrolysis of Water "Helios Taking Power from the Sun. [cited; Available from: media.nasaexplores.com/lesson/01-009-9-12_1.pdf.

5. M. Cifrain and K. Kordesch, Hydrogen/Oxygen (air) Fuel Cells with alkaline Electrolysis, Handbook of Fuel Cells, chapter 14. 2003.

6. Chris Rayment and Scott Sherwin, Introduction to Fuel Cell Technology, Alkaline Fuel Cells, chapter 5 2003: Dept. of Aerospace and Mechanical Engineering, University of Notre Dame, USA.

7. Accidental Chemical Corporation, OxyChem Caustic Potash Handbook. 2000.

8. K. Kordesch and M. Cifrain, A Comparision between the Alkaline Fuel Cell (AFC) and the Polymer Electrolyte Membrane (PEM) Fuel Cell, Handbook of Fuel Cells, chapter 58. 2003. 